\title{
Absurd avatars, transcultural relations: Elia Suleiman, Franco-Palestinian filmmaking and beyond
}

Article

Accepted Version

Chamarette, J. ORCID: https://orcid.org/0000-0003-0701-1514 (2014) Absurd avatars, transcultural relations: Elia Suleiman, Franco-Palestinian filmmaking and beyond. Modern \& Contemporary France, 22 (1). pp. 85-102. ISSN 0963-9489 doi: https://doi.org/10.1080/09639489.2013.867152 Available at https://centaur.reading.ac.uk/92945/

It is advisable to refer to the publisher's version if you intend to cite from the work. See Guidance on citing.

To link to this article DOI: http://dx.doi.org/10.1080/09639489.2013.867152

Publisher: Taylor \& Francis

All outputs in CentAUR are protected by Intellectual Property Rights law, including copyright law. Copyright and IPR is retained by the creators or other copyright holders. Terms and conditions for use of this material are defined in the End User Agreement.

www.reading.ac.uk/centaur 
Central Archive at the University of Reading

Reading's research outputs online 


\section{Absurd avatars, transcultural relations: Elia Suleiman, Franco-Palestinian filmmaking, and beyond}

\section{Abstract:}

This article illuminates the threads of connection drawing together the work of the Palestinian filmmaker Elia Suleiman and French cultural production, while acknowledging the broader international contexts of these connections. The transcultural relations identified in the article title are a means of articulating these concerns. Suleiman's films, funded by French production companies and supported by French film festivals, have a tacit connection to France. Suleiman's mute selfrepresentation within his films also draws upon auteurist and absurdist tropes familiar to European literature and art in the $20^{\text {th }}$ century. First discussing the broader cultural and geopolitical contexts of Franco- Palestinian filmmaking, the article then engages closely with critical tropes of the Absurd and human gesture in relation both to the critical reception of Suleiman's films, and the films' aesthetics: specifically in his recent feature films Divine Intervention (2002) and Le Temps qu'il reste/The Time that Remains (2009). Offering an alternative articulation of these complex transcultural relationships, the article explores Suleiman's position as a mute filmic figure and auteur director. It re-opens an often 'unspoken' dialogue of FrancoPalestinian cinematic relations which has been frequently designated as historical or political, rather than also and in equal measure, cultural, aesthetic, ethical and personal. At the same time, it seeks to open out these dialogues beyond France and Palestine, towards transcultural relations between Europe, the Middle East, North Africa, and North America. 


\section{RÉSUMÉ}

Cet essai a pour but d'éclairer les relations « inexprimés » entre l'œuvre d'Elia Suleiman, cinéaste palestinien, et la production culturelle de la France, tout en reconnaissant les contextes internationaux et intertextuels au delà de ces relations réciproques. La notion de cette relation « transculturelle », évoquée dans le titre, tente d'articuler ces rapports. A cause du soutien des maisons de production et des fonds français apporté aux films de Suleiman, et grâce à la participation régulière de Suleiman dans les festivals de film en France, il existe une connexion tacite entre les films de Suleiman, et la France métropolitaine. En outre, dans ses films l'autoportrait muet de Suleiman fait référence aux tropes de l'absurde et du film d'auteur, qui sont évidents dans la littérature et le septième art de l'Europe du vingtième siècle. Cet article examine en premier lieu les contextes culturels et géopolitiques des relations filmiques franco-palestiniens. En deuxième lieu, l'article s'engage profondément avec les tropes analytiques de l'absurde, et du geste humain, s'appuyant à la fois sur l'accueil critique des œuvres, et sur l'esthétique des films. Plus précisément, l'article se concentre sur les deux derniers films de Suleiman : Divine Intervention (2002) et Le Temps qu'il reste (2009). En exposant une articulation plus exacte des relations transculturelles et complexes, l'essai interroge la situation de Suleiman en tant que figure muet dans ses films, et en tant qu'auteur-réalisateur. L'essai propose d'ouvrir de nouveau le dialogue souvent inexprimé concernant les relations cinématographiques franco-palestiniens : dialogue souvent identifié en termes d'histoire ou de politique, au lieu de quoi cet article vise à cerner ses facettes à la fois culturelles, esthétiques, éthiques et personnels. En même temps, il vise à ouvrir ces 
dialogues entre la France et la Palestine pour inclure les relations transculturelles entre l'Europe, le Moyen Orient, le nord d'Afrique, et le nord d'Amérique.

\section{ARTICLE:}

As recent film scholarship has argued, there has never been a time at which cinema was not already 'transnational' in its modes of production and formal or aesthetic structures (see, for instance, Higson 2002, Naficy 2001, Bergfelder 2005, Ezra and Rowden 2006, Higbee and Hwee Lim 2010). Cinema's complex relationships to international politics and economics has also never been reducible to a series of radial relationships between the productions of one focal country - such as France - and its various 'others'. Nonetheless, as both an art form and a focal point of industrial production and economic expenditure, cinema offers a privileged site through which to unravel relationships between politics, aesthetics, and intertextual reference across cultures, languages and national identities. The focus of this article is drawn small, in that it attends to the transcultural relations between recent films by Palestinian filmmaker Elia Suleiman, and the political and aesthetic indices of Franco-Palestinian cultural identity that might be traced within and beyond these works. It does so, however, with a clear acknowledgement that the 'transcultural relations' thus identified do not speak exclusively to bilateral Franco-Palestinian reciprocity: the geopolitical complexities of this relationship alone would make this argument ring hollow. Nonetheless, to simply describe the industrial, aesthetic and formal resonances within Suleiman's work solely as 'intertextual' risks silencing the political and personal connections between France and Palestine that are brought forward in Suleiman's works. Hence, I use the term 'transcultural relation' to attempt to bring forth both the specificity of this unusual cultural, geopolitical and industrial relationship between France and Palestine, and its imbrication within other complex 
cultural fabrics: European, Middle Eastern, North African, North American. Shifting from the industrial and political to the aesthetic, this article attempts to articulate first the ambiguous position that Suleiman maintains with regard to France as a Palestinian filmmaker, and second the equivocal relation between cultural form and cultural identity expressed via modes of comedy and self-representation in Suleiman's films.

Elia Suleiman has, since 2002, been recognised as a leading figure in international auteur cinema. Born in Nazareth, but a former resident of New York for over a decade between 1982 and 1993, Suleiman's return to Israel and the Occupied Territories in 1994 took an academic form. Suleiman is a Professor at Bir Zeit University in Ramallah, having been appointed to establish a new Department of Film and Media, and also teaches at the European Graduate School in Saas-Fee, Switzerland. Interviews from 2000 suggest that he lives in Paris and returns to Israel and Palestine only as a frequent visitor (see Suleiman and Bourlond 2000), though the precise location of his home is perhaps moot, given his own self definition as a visitor and a 'present absentee' (Suleiman and Cutler 2011). The complexity and subversive nature of Suleiman's filmmaking is intimately tied up with the prominence of Suleiman himself as a central figure within them: a mute avatar named ES, who has inhabited all of his films, both feature-length and short. In a manner that has drawn formal comparison with French filmmakers such as Jacques Tati and Jean-Luc Godard, the marks of Suleiman's physical presence on screen act as a node through which the fragmented narratives of his films shift and reshape. His films' combination of humour, seriousness and body language have also attracted critical comparisons with figures such as Buster Keaton and the aforementioned Tati (Thirion 2009, Suleiman and Cutler 2011). Perhaps unsurprisingly for a figure that appears as predominantly mute in his films, much of the scholarship on Suleiman is devoted to 
interviews with him, as a means of engaging meaningfully with his works. Extended formal analyses of his works are perhaps less frequent, though Gertz and Khleifi's chapter on Suleiman in their book, Palestinian Cinema: Landscape, Trauma and Memory is a notable and brilliant exception (2008).

Suleiman's position as auteur-provocateur, and the absurdist tone of his works, in particular the 'chronicle trilogy', Chronicle of a Disappearance (1996), Divine Intervention: A Chronicle of Love and Pain (2002), and Le Temps qu'il Reste/The Time That Remains: Chronicle of a Present Absentee (2009), have received widespread critical acclaim. Each of Suleiman's feature films are fragmented and episodic in structure, evading linear narrative in favour of vignettes, dream-sequences and long takes. The films shift between vignettes of everyday life and moments where violence erupts, either in intimate quotidian acts of aggression, or in structures of fantasy, dreamscape or absurd incongruity. Chronicle of a Disappearance's lengthy waiting sequences in front of the Holyland souvenir shop, or the repeated reenactments of sequences around Suleiman's family breakfast table featured in Le Temps qu'il reste/The Time That Remains, serve as examples of the former. Instances of quotidian acts of violence take place in Divine Intervention's lengthy first chapter, where neighbours break up each other's driveways, puncture footballs with a knife, or throw garbage into one another's gardens. Violence enacted within the dreamscape recalls Divine Intervention's famous Ninja scene. In this sequence, the female protagonist, with nothing but a shield and a keffiyeh wrapped around her head (the agrarian scarf, now a Palestinian symbol of armed resistance), bloodlessly dispenses a pack of armed soldiers, themselves ironically besporting t-shirts bearing the slogan of 'Peace Now', the name of the left-wing Jewish-Israeli activist and advocacy group (see Morag 2008: 21). Both Patricia Pisters and Janet Harbord have explored this 
sequence - from the perspective of a refreshed engagement between Deleuzian thought and postcolonial burlesque (Pisters 2010: 205-14) and with regard to a magical suspension of temporality (Harbord 2007: 159) - respectively.

The aesthetic construction of the films, and in particular their attention to juxtapositions of the mundane and the fantastical or transcendent, absurdist and deadpan performance, and a proliferation of poetic space at the expense of linear narrative, suggest more than a merely passing familiarity with European auteurist filmmakers such as Godard, Bresson, and Antonioni (see Suleiman and Butler 2003, 66). Although one might easily read this somewhat overdetermined critical comparison as a mode of 'unthinking Eurocentrism' (Shohat and Stam 1994), the presence of Suleiman as an international intellectual figure of cinema, as significant as, for example, Emir Kusturica or Abbas Kiarostami, suggests that this is not purely a case of Eurocentric cultural appropriation. Rather, it suggests a more intriguing transcultural relationship, resonant with recent conceptualisations of transnational cinemas (Galt 2006, Ezra and Rowden 2006, Elsaesser 2005). Effectively, Suleiman's cinematic relationships to France and French production shed light on the complex cultural politics of cinematic production that implicates France within contemporary Palestinian cultural expression, and invoke a broader sense of intertextual relations at work across European and Middle Eastern cinematic forms.

Suleiman's films, like many works of so-called 'world cinema' that receive successful plaudits in the European Film Festivals circuit, have a close relationship to France, in their structures of funding and distribution, in their stylistic relationships to well-discussed historical forms of performance and artistic practice, and in Suleiman's own participation within European intellectual circles (he has been a visiting professor at a number of European universities, not to mention his 
professorship at the European Graduate School, which regularly recruits some of the most famous artists, scholars, writers and intellectuals in the world for its Graduate Summer Schools). Suleiman's canonisation in French critical and festival circles (Divine Intervention won the Prix du jury at Cannes in 2002; he served on the Jury himself in 2006), and the co-financing of many of his films by French production companies such as ARTE France cinéma, or by French government-funded organisations such as the Centre National de la Cinématographie (CNC), offer a very different cultural reception to the one which produced some controversy in the US after the release of his second feature film, Divine Intervention. The furore surrounding his submission of Divine Intervention to the US Academy Awards in 2002 for 'Best Foreign Film' is well documented: the film was initially rejected by the selection committee, not on grounds of quality, but because Palestine was not recognised by the United Nations as a foreign country, in spite of existing exceptions being made for Taiwan and Hong Kong (Jacinto 2002). In the subsequent year, however, Divine Intervention was successfully submitted to the Academy Awards, and paved the way for submissions from Palestine in each consecutive year.

The prominence of Divine Intervention, and of Le Temps qu'il reste/The Time That Remains (with its implicit reference to Proust) in an international arena, resituates Suleiman's work beyond its regional contexts, thereby also inviting parallels beyond his immediate Palestinian contemporaries, not least to the country which has financially and culturally supported Palestinian filmmaking for some time. France plays a major role in supporting Palestinian filmmaking: in particular, the CNC, ARTE France cinéma, Canal+ and Ognon Pictures, have funded a significant proportion of Palestinian films that have received international acclaim (and Palestinian film depends upon this funding as it lacks the internal infrastructure and 
funds to finance itself). In addition to Suleiman's films, Bab El Shams (Yousry Nasrallah, 2004), Paradise Now (Hany Abu-Assad, 2005), and, most recently, Five Broken Cameras (Emad Burnat and Guy Davidi, 2011) received funding from at least one of these four funders/producers.

The form and structure of all three of Suleiman's chronicle films also make a wider appeal to French cultural iconography - both Jacques Tati’s sight gags and mute chaotic drives, and the oblique anti-narratives of Godard are acknowledged influences (Butler and Suleiman 2003: 66; Gertz and Khleifi 2008: 182) - and European incarnations of avant-garde address, such as the Absurd and the surreal (though this article will later challenge the notion of the Absurd as European per se). At the same time, the elliptical narrative and spatial logics of Suleiman's films recommend themselves well to a reading of accented and hybrid forms of intercultural cinema, in a manner that theorists such as Hamid Naficy (2001) and Laura U. Marks (2000) have so fruitfully explored. Consequently, while the following section of this article is ethically compelled to attend to some of the historical and contextual issues connecting France to the Israeli-Palestinian conflict, these tacit and sometimes explicit political relations should also be brought into contact with the cultural and aesthetic specificities of Suleiman's filmmaking, and the broader transnational considerations of contemporary art cinema. Just as the bilateral focus of FrancoPalestinian relations co-exists with a complex interplay of international relations in the Middle East, so too do the stylistic and intertextual elements of Suleiman's filmmaking also bring into play other silent partners beyond France and Palestine, as subsequent sections demonstrate.

\section{Directness and Indirectness: France, Palestine and Suleiman}


In the light of France's recent military interventions in Mali to combat Islamist factions in the North of the country, and the potentially linked hostage crisis and siege at the Amenas gas field in central-eastern Algeria, it is clear that France continues to have a complicated and pivotal relationship to the on-going volatility in the Middle East and Francophone Africa (See Al-Jazeera 2013, Le Monde 2013). ${ }^{1}$ Events which have in the last few years resulted variously in military interventions and acts of extreme violence such as those in Mali and Algeria, in a fight for democracy and the rights of people during the Arab Spring, and indeed the emerging and often violently contested power of Islamist groups in government - for instance, the rise of Islamism in Tunisia since 2010 that the filmmaker Nadia Al-Fani has documented in her film, Laïcité, Inch'Allah! (2011) - are not simply relegated to a position geographically distant from Europe. France and Europe are deeply implicated in the crises that are continuing to erupt in French-speaking North and East Africa, and beyond this, in the Middle East.

France's continued strategic and cultural involvement in the affairs of Algeria after its independence on 5 July 1962, and its relationships to sub-Saharan African nations such as Mali (which obtained independence from France on 20 June 1960) are well documented. They are also part of an on-going postcolonial relationship whose dynamic shifts in diplomatic and political relations have been discussed in detail, for instance, by Tony Chafer in his work on 'la Françafrique' with respect to sub-Saharan Africa (2006), and where, for example, the cultural and intellectual traces of France and Algeria's continued dialogue have been mapped by scholars such as Guy Austin (2012) and Jane Hiddleston (2006). However, the historical and political reach of France is not limited to the postcolonial Francophonie. Affairs in the Middle East 
continue to be pressing concerns, which certainly implicate France and the IsraeliPalestinian conflict in its international relations, and pertain to France's on-going spheres of influence. Such a topic ostensibly exceeds the scope of this article; however, there are some historical and cultural precedents, which might bring clarity to a context in which French and Palestinian film cultures maintain some form of tacit dialogue.

Up until the declaration of Algerian Independence in 1962, France had, perhaps unsurprisingly, received a hostile reception from Arab nations. However, French historians such as Sieffert and Rondot have acknowledged the historical rapprochement between France and Arab nations after Algerian independence. In particular, this easing of relations between France and the Arab nations is substantially attributed to France's - and specifically, Charles de Gaulle's - public addresses with regard to the 'June War' of 1967, where, in six days, Israel seized land from Palestinian territories, Jordan and Egypt, including the Sinai peninsula, the West Bank, The Golan Heights and the Gaza strip. De Gaulle's presidential denunciation of Israel's actions in the June 1967 war led also to an acknowledgement of the inevitability of the emergence of a Palestinian resistance to oppression, described in Philippe Rondot's account of France and Palestine's political relations from 1948 to 1987, 'France and Palestine: From Charles de Gaulle to Francois Mitterrand'. Rondot cites de Gaulle's comments at a press conference on 27 November 1967: "the Israeli occupation of the territories it captured cannot continue without oppression, repression, expulsions, nor without the emergence over time of a resistance it will then label as terrorism" (Rondot 1987: 89). Rondot also documents De Gaulle's contentious, and arguably anti-Semitic criticisms of 'the Jewish people' six months after the June war: an issue also picked up by the historian Denis Sieffert, who, 
however, acknowledges both the potentially anti-Semitic and the pro-Jewish, aggrandizing rhetoric of de Gaulle's November 1967 speech (see Sieffert 2004, 120).

1967, according to both Rondot and Sieffert, marked a turning point in France's political and cultural attitudes to Palestine, which experienced significant stages of further rapprochement under the leadership of Georges Pompidou, Valéry Giscard D’Estaing and François Mitterrand, (see Rondot 1987). However, the French cultural and intellectual relationships to Palestine are also complex, and not so easily negotiated through an understanding of France's policies on international relations or the speeches of its leaders. Lincoln Z. Shlensky offers an insightful critique of leftwing intellectuals' paradoxical political support of Algerian independence, and their simultaneous silence on issues of political oppression and violence in the emerging state of Israel. In an unusual critique of Chris Marker's political foresight in his film, Description d'un combat (1960), Shlensky argues that:

Like most other Europeans prior to the discursive shift linked to the 1967 ArabIsraeli War, Marker considers the indigenous Arab inhabitants of Palestine to be incidental to the European historical narrative in which the founding of a Jewish state in the biblical Land of Israel only can be seen as the redemptive answer to Europe's moral fall. (Shlensky 2010, 111)

Shlensky argues that Palestine remained until 1967 a kind of ideological 'blind spot' in the activities of French intellectuals and filmmakers who had previously supported the rights of dissident Algerians, but whose attentiveness to the fascist, genocidal and anti-Semitic European contexts that effectively authorised the establishment of the Jewish State of Israel, set the status of long-standing Arab inhabitants of former 
Palestine to one side. With the exception of films such as Jean-Luc Godard and AnneMarie Miéville's Ici et ailleurs (1976), Shlensky suggests that few French filmmakers took on the task of engaging explicitly with the Israeli-Palestinian conflict in terms of its impact upon Palestinians. However, what he also suggests is that the IsraeliPalestinian conflict has, and continues to have an on-going influence on the cultural imaginary of France. Shlensky argues that French-speaking cinema in Europe has experienced a wave of filmmaking that engages, either directly or tangentially with the Israeli-Palestinian conflict, particularly since 2000. According to Shlensky, the concerns raised with regard to conflict elsewhere (in the Middle East) raise more particular issues of conflict and destabilised identity within France:

For France, and more generally for Francophone Europe, the outbreak of the Palestinian Second Intifada has reactivated a set of social conflicts whose historical and geopolitical connection to the Israeli-Palestinian conflict is only indirect, but whose ramifications in the media and the public sphere indicate a complex symbolic linkage between Middle Eastern politics and Francophone culture. This linkage remains largely unarticulated, and its meaning veiled, in Francophone public discourse and particularly in the visual media, where screen memories and graphic snapshots of historically disjointed événements often substitute for analysis. (105)

Shlensky's essay focuses principally on invocations of the Israeli-Palestinian conflict in a range of French and French-speaking films, predominantly but not exclusively dating from the time of the second Intifada from 2000-2006: a period of intensified conflict between Israelis and Palestinians, which resulted in another re- 
drawing of the Israeli-Palestinian map, with complex disputes over the governing authorities in charge of Gaza, the West Bank, and non-Palestinian Israel. However, while Shlensky argues that the distant invocations of the conflict in the films he cites, serve as disavowed 'mirrors' to France's own problematic internal identity, I would like to suggest that close engagement with the two most recent films from one of the most internationally prominent Palestinian filmmakers, can also read this 'complex symbolic linkage' in a reciprocal direction. By doing this, I do not want to imply that Palestinian filmmaking is somehow irrevocably connected to French national identity as some kind of dialectical exchange - and indeed Shlensky explicitly indicates France's indirect connections to historical Israel and Palestine, which effectively subsume the Israel-Palestinian conflict within a symbolic sphere of disavowed French 'otherness' (2010). Rather, the analysis of formal and intertextual strategies in Suleiman's films which follow, imply an unspoken dialogue: that notions of the absurd, of fantasy, and of auteurist gestures of mute self-narrative co-identify between elements of certain French (and European) films and literature, and Suleiman's contemporary productions. These form a rich ground of transcultural relations, that neither situates Palestine as France's cultural 'other', nor does it ignore the complex historical, geo-political, and intellectual relations beyond the two within Europe, the Middle East, North Africa and the US.

The richness of these transcultural encounters might in turn propose that, much as Hamid Dabashi has argued in his recent work on the Arab Spring, the abstract literary and poetic concerns which circulate in certain forms of Arab and Middle Eastern art and culture can also offer a deeper, more hopeful notion of transcultural political engagement, in a manner that has extensive repercussions for art all over the world. In his book, The Arab Spring: The End of Postcolonialism, Dabashi argues that 
literary humanism, rather than current affairs, offer a more complex reasoning for, and explanation of, forms of contemporary cultural resistance, which long precede international events:

The revolutions in fact have their roots in far deeper normative tropes of literary humanism in the Arab world, and thus require grounding in the humanities as the paramount frame of reference. A novel of Sun'allah Ibrahim, a poem by Mahmoud Darwish, or a film directed by Elia Suleiman are far more potent frames for the emotive universe of these revolutions. (Dabashi 2012, 225)

The fact that, in this context, Dabashi cites two Palestinian artists: the poet Mahmoud Darwish, and filmmaker Elia Suleiman, suggests that Palestine forms a crucial cultural context, not only for France and Europe's cultural imaginary, but also the cultural imaginary of the Middle East. Olivia C. Harrison has suggested precisely such a transcultural connection in her article, 'Staging Palestine in France-Algeria: Popular Theater and the Politics of Transcolonial Comparison', where she argues that:

The transnational mobilization of peoples across the Arab world today in many ways represents a reactivation and reformulation of prior cross-regional dialogues that have been largely eclipsed in our critical tendency to privilege regional cartographies inherited from colonial science: Maghreb and Mashreq, North Africa and Middle East. The dissemination of revolt across this vast and heterogeneous region serves as a reminder of the limits of these cartographies, and of the importance of attending to connections that bridge them. (Harrison 2012, 27) 
This notion of attention to connections that bridge countries such as Algeria, Tunisian and Palestine also implicitly and explicitly draws upon a linguistic and cultural heritage dominated by France as an intervening European and postcolonial power, even if that postcolonial framework is distinct and different in each case (and in the case of Palestine, is indirect and indistinct. While there is a case to be made for a somewhat lopsided reciprocal reading of contemporary Palestinian film and the French cultural imaginary, this should not annihilate cultural difference, nor should it overstate a connection between French-speaking film and Palestinian film where complex international cultural relations are also at play. Instead, the transcultural relations identified in this article recognise both the concrete economic and political conditions that connect contemporary Palestinian filmmaking to France, and the poetic, gestural and figural resonances played out within and between the films examined here, with relation to France's own cinematic intertextualities. The remainder of this article, then, explores the formal and aesthetic contacts between Suleiman's work and cultural tropes with a signficant presence within France, but without exclusive attribution as French. As a result, this transcultural approach reconsiders the resistant nature of formal strategies which implicate concepts such as the absurdly animated object and mute gesture, in the light of their reciprocal, if unequal, connections across two cultures otherwise tensely implicated in the on-going and violent power struggles in the Occupied Territories, and elsewhere in the Middle Eastern nations.

\section{Red BALlOONS AND DEAD ZoNes: DIVINE INTERVENTION (2002)}

One of the most striking sequences in Divine Intervention takes place during one of the episodic breaks in the film, when ES, the mute figure played by Elia Suleiman, 
travels from his apartment in Jerusalem to meet with his Palestinian lover from Ramallah, at a disused piece of ground beside the A-Ram check point which separates the two cities. Unable to move freely between Jerusalem and Ramallah (ES's Palestinian lover is prevented from crossing the road block to enter Jerusalem) instead the two lovers sit silently, side by side, in ES's car next to the checkpoint. A familiar pattern of shots establishes the on-going nature of these encounters: the frontal two shot with both ES and the woman's face staring impassively outward is followed by a static close-up of their hands intertwined between the two front car seats; their palms and fingers caress, slipping over one another in a display of their physical and sensual attraction. Long lateral takes of ES's face, are followed by a reverse shot of the face of his lover: neither speaks and their facial expressions betray neither happiness nor distress, nor any kind of emotion bar mute observation.

During one of these episodes, ES's lover pulls up next to ES's car, noticing a post-it note taped to the window as it is automatically raised. The post-it reads in Arabic: "I am crazy because I love you" - a motif foreshadowed earlier in the film where it was scrawled on the wall by a disused bus stop. At this point, intercuts of medium-paced shot-reverse-shot editing, which establish point of view from ES's lover, are followed by a medium shot of Suleiman, from the waist up, his face turned towards the camera. ES produces a flaccid red balloon, which he then proceeds to inflate, revealing the caricatured face of Yasir Arafat, former leader of the Palestinian Liberation Organisation, and later the Palestinian National Authority (and who died in 2004 in unresolved circumstances). The balloon rapidly inflates in size alongside ES's head, briefly juxtaposing the inflated red balloon caricature with ES's mask-like visage. Opening the sunroof of the car, ES then releases the balloon, which rises slowly above the car, and tracks forward toward the sentry tower of the checkpoint. 
As the camera views this movement from a static frame, the balloon rises, causing consternation amongst the Israeli soldiers manning the checkpoint, who argue about shooting it down. Distracted by the balloon, they barely notice a car, implicitly containing ES and his lover, which passes through the checkpoint without resistance, and speeds towards Jerusalem. The arresting sequence which follows, depicts the balloon floating above and past some of the most iconic structures of this holy city the Dome of the Rock and in particular the Al-Aqsa mosque, identified by Gertz and Khleifi as symbolizing 'Palestinian unity - its present, its past, and its future - more than any other image' (Gertz and Khleifi 2008, 180). The balloon comically transgresses the boundaries established by contemporary geopolitics and military occupation; it also creates a simultaneously absurd and poignant intervention in a landscape heavily predetermined by centuries of religious conflict and assertions of land rights.

However, since the balloon has a face: that of Arafat's smiling visage, it also occupies an interstitial boundary between animacy and inanimacy. The patterns of movement of the balloon are not random: rather they are diegetically pre-determined (and, in the shot of the balloon soaring across the Jerusalem, the image of the balloon is clearly a digitally enhanced addition, gradually increasing in size as if heading directly for the camera). While the sequence inhabits a transitional position between fantasy, comedy and narrative continuity, the agency of the balloon, travelling across militarized dead zones and iconic landscapes, has significant affinities with the animate, sentient red balloon that populates Albert Lamorisse's film Le Ballon Rouge (1956). Both films suggest animacy, if not sentience on the part of the balloon; both films use the form of the balloon above the city as a means of transgressing public and private boundaries, as well as deconstructing the aerial mapping of contested and 
damaged spaces: bombsites in Paris and fractured urban space in Jerusalem and Ramallah, respectively. Both red balloons contrast the humour of inanimate intentionality with the limits of human space. While Lamorisse's faceless, eyeless, but nonetheless sentient, hearing and perceiving balloon mimics human movement and 'plays' with the film's young boy protagonist (played by Lamorisse's son, Pascal), Suleiman's balloon seems both to interrupt existing geo-political and cultural topographies, and to echo, rather than embrace, semi-sentient behaviour. It is a harbinger of mischief: the caricature of Arafat both affectionately iconizes and mocks, and implies subversiveness in the expressiveness of the balloon's 'face'. Where Lamorisse's ballon rouge and Suleiman's Arafat balloon differ is in the distinctions between the movements of the balloon, and the fascination it offers for its diegetic spectators. The manner in which Suleiman's Arafat balloon redistributes permitted and forbidden space seems also to operate as a kind of metaphor for a mobile camera: one which is no longer attached to the constraints of a human, or indeed, Palestinian body, but which is free to capture indifferently the faces of bewildered Israeli soldiers and the picture-postcard setting of the Holy Land. This revisioning of cinematic form and the implication of geo-political cross-cultural entrapment and fantasies of spatial freedom is particularly significant given that Le Ballon Rouge is also recontextualised in the Taiwanese filmmaker Hou Hsiao-hsien's 2007 film produced for the Musée d'Orsay, Le Voyage du ballon rouge: the balloon as a spatial metaphor of transgression also become cinematic objects that establish transcultural relationships between France, Palestine, and, beyond the immediate concerns of this article, Taiwan. 


\section{Mute Bodies And Absurd Poetics: Le Temps qu'Il reste/The Time That}

\section{REMAINS (2009)}

As is evident in the vignette described above, a combination of grave seriousness and absurd levity forms a trope of Suleiman's films. A poetics of the absurd permeates, and this absurdity traverses the cinematic landscapes of both Divine Intervention and The Time That Remains. While it is beyond the scope of this article to discuss the transcultural intertextuality of the Absurd within European literary and cultural production, the work of Beckett between English, Irish and French cultures, or Ionesco's situatedness between Romanian literary criticism and French theatre, might place enough of a question mark over the 'Frenchness' of the absurd, in spite of the rich presence of the absurd within $20^{\text {th }}$ century French literary culture (Anouilh, Camus, Genet among others.) In more contemporary settings, one might also think of the South African artist William Kentridge's multi-channel installation I am not me, the horse is not mine from 2008, an installation of moving image and stop-motion animation, inspired by the Russian writer Nikolai Gogol's absurd short story from 1835, The Nose (2011), exhibited in 2012-13 in the Tanks at Tate Modern, and previously at the Jeu de Paume in Paris. Historically and contemporaneously, creative explorations of the absurd seem often implicated in transcultural activity, emerging within the content, form and the frequently political and poetic concerns of their work; nonetheless France seems to have provided a particularly strong platform for the emergence of absurdist works in the $20^{\text {th }}$ and $21^{\text {st }}$ centuries. In this regard, Suleiman's adoption of absurdist performance and staging strategies in his films, and their imbrication with the mundane and the urbane, resonates with cultural intertextuality. At the same time, absurdism's location in 'no place' as Martin Esslin (1970) has described it suggests that cultural dislocation is effectively a precedent and 
a prerequisite for absurdist forms, in spite of, or perhaps because of, their significant emergence in France.

Both Divine Intervention and The Time That Remains present a kind of dislocated human repetition compulsion in random acts: these Beckett-like forms of mundane performance are so concentrated and singular that they become theatrical, in a manner which resonates with Beckett's Fin de partie, Krapp's Last Tape, or the television play Eh Joe (Beckett 1957, 1967, 1959). In Suleiman's work, an absurd poetics of stillness and gesture resonates intertextually between intercultural absurdist forms. The critical reception of the films picks up on this absurdist legacy too: Stanley Kauffmann in the Republic spoke of Chronicle of a Disappearance as 'a film of the Absurd. If Ionesco had been a Palestinian and a filmmaker, he might have made it.... Like all good Absurdists, [Suleiman] looks at things bifocally: from the point of view of a fly on the wall and under the eye of eternity' (cited in Suleiman and Bourlond 2000, 95).

We might witness, for example, in Divine Intervention, a static frontal frame of ES's father, camera height matched just at the eye line of the seated man, who is perched at the breakfast table with a hard boiled egg, coffee cup and small pile of letters, birds chirping monotonously outside. In a hospital sequence later in the film (the same hospital where ES' father lies dying) the near-deathly stillness of three men in their sixties staged laterally in front of the camera, is slowly dissolved as they shuffle out of bed to walk up and down a corridor outside, smoking and pacing compulsively alongside nurses, doctors, the elderly, the sick and the injured. B. Ruby Rich describes this sequence as a 'hospital of the absurd', noting the Beckett-like strains of such a mix of death and death-drive (Rich 2003). Both Divine Intervention, and its partner film, The Time That Remains, reveal a gestural preference for lengthy 
periods of bodily stillness and minimization of movement, whether forced or selfimposed - sitting, lying, and smoking. These issues have been critically discussed, often with regard to the physical constraints of Palestinian life: imitating on an intimate, bodily level the spatial claustrophobia of constricted domestic and geopolitical space (Geertz and Khleifi 2008, 173-9). However, they also draw upon a gestural economy of comic exhaustion, resignation in the face of finitude, and existential entropy, that resonates with a physical comedy of the Absurd.

In both films, these sequences of near-absolute stasis are juxtaposed with moments of extreme athleticism or superhuman strength: for instance, the ninja sequence in Divine Intervention or ES's pole vault over the wall separating the West Bank from Israel in one of the penultimate sequences from The Time That Remains. However, as Paul Martin Eve has discussed, the episodic structure of The Time That Remains makes a shift from rich historical detail and diegetic space structured in a more 'classical' narrative form in the early episodes of the film covering events after the 1948 creation of the Israeli state and Palestinian surrender to Israeli forces, to a cartography and gestural economy of stillness in the later, present-day episode (Eve 2010, 147).

In his volume on the Theatre of the Absurd, Martin Esslin argues that the 'pure' theatrical elements of the Theatre of the Absurd are 'anti-literary', in the sense that they obviate the necessity of language as a meaningful structure. In the cinematic form of Divine Intervention and The Time that Remains, the theatricality of gesture might also be described as a kind of abstraction from diegetic events and narrative; Suleiman himself describes this as a kind of poesis, shifting between hyperrealism and the absurd (see Suleiman and Bourlond 2000: 101). Esslin writes: 
The age-old traditions that the Theatre of the Absurd displays in new and individually varied combinations - and, of course, as the expression of wholly contemporary problems and preoccupations - might perhaps be classed under the headings of:

Pure theatre; i.e. abstract scenic effects as they are familiar in the circus of revue, in the work of jugglers, acrobats, bullfighters, or mimes

Clowning, fooling and mad-scenes

Verbal nonsense

The literature of dream and fantasy, which often has a strong allegorical component. (Esslin 1970: 318)

In a typical stylistic trait, Suleiman makes use of deep sets and static, lateral framing in interior sequences: these serve to emphasis the transition between hyperrealism and absurdity. For instance, in the sequences in his parents' apartment in The Time That Remains, the camera sits side-on to the (minimal) action within the apartment as if positioned as a fourth wall. The scenography of the apartment is structured much like a theatrical stage: off-screen space is used both for comic and tragic effect. For example, during the sequence in the 'present' and final episode of The Time That Remains, ES, dressed in black pyjamas, watches the movements of the two carers in his mother's apartment. Tightly framed within the frame by an internal doorway and facing the camera dead ahead, ES's head is slung low, craning forward slightly. His neck turns one way and then the other, in an action that comically imitates like a horizontal tennis match. The accompanying matched sound beyond the frame, foregrounds the subsequent cut to a familiar reverse shot of the apartment's 
living room, as carers traverse the room, in through one size of the shot's frame, and out through the other, pushing mops ahead of them like $21^{\text {st }}$ century domestic jousters.

This slouched, standing gesture of ES/Suleiman's body is repeated unfailingly throughout Suleiman's feature films: his shoulders slightly hunched, positioned to the left of the screen. His eyes gaze outward and away from the camera, the face is passive and unmoving, incarnating an aesthetics of the deadpan that has so often been critically described as 'Keatonesque' of 'Tati-like'. ES's standing gesture is a vision of passivity: attentiveness leaves his body in search of other sources of attention/observation, which are then cinematically refound through off-screen sound and reverse-shot cuts. Often framed internally by doors or lighting along either frontal plane or lateral profile plane, no 360 degree vision of ES's character is ever given: we are limited to the planes of performance, to comically hyper stylised observation of an observer. Absurdity is intertextually and corporeally invested in the restraint and physicality of Suleiman's body on screen: the theatricality and bodily performance of the absurd becomes a vehicle of cultural transmission, resonating between European, North American and Palestinian modalities of physical comedy.

What differs perhaps in The Time That Remains, compared to Divine Intervention, is that ES takes on avatar form as a child and as an adolescent. The framing of the adolescent ES is much like Suleiman's framing of himself as ES; however, the childhood ES is evidently more mobile. In one sequence, shot in profile at the kitchen table with the two actors performing Suleiman's parents, the child ES figure sips slowly at his breakfast tea; in the corridor of his school he is shot in profile standing, head bowed, as his Headteacher shouts at him "Who told you America was Imperialist?". In a subsequent scene, the camera sits at a distance at the foot of the stairs to ES's family apartment, watching the child's retreating back and carefully 
rising knees as he climbs carefully up the steps to the apartment. In a subsequent interior shot, the child ES carefully opens the door to its fullest extent, pushing at the handle to ensure it is in place, before cautiously bringing in the bowl of lentils he has left on the wall's sill outside, and depositing them equally gently in the bin. Framed by the doorway in this manner, the child ES recalls a similar juxtaposition between stillness and care of gesture, and the sudden bursts of activity, seen in Divine Intervention.

One of the most destructive sequences in the Divine Intervention is a consequence of an everyday gesture performed by ES: shot in profile again, but this time in a moving car (scenery outside the vehicle passes by in a blur), ES raises his arm to eat an apricot. A few seconds later, he throws the stone out of the open car window: the ricochet of the stone off a metal object is first heard, and then in a sudden cut, repeating the diegetic chronology of events by a few seconds, as if in action replay, the apricot stone hits the side of a tank. Almost immediately the tank explodes in a huge fireball. This sequence occurs in Divine Intervention as a kind of second chapter to mundane events: the first chapter is occupied with the squabbles and petty unpleasantness of a group of Palestinian neighbours in Nazareth, who repeat senseless acts, no doubt as a form of repressed reaction to their broader experience of political oppression and harassment by the Israeli police, among others. That this build-up of small forms of aggression - throwing glass bottles from the top of an unfinished building extension; puncturing the football of a passing boy whose ball skills send the ball up onto the roof of the building; the daily exertions of a man who throws his rubbish bags over the wall and into his neighbour's garden - is directly followed by a scene of massive destruction, appears cathartically to ease the tension of the previous sequences. Both darkly humorous and threatening, the sudden 
explosion of massive violence against a military vehicle seems to fulfil an entirely non-humorous desire to break the oppressive circumstances, both self-imposed and governmentally sanctioned, of this group of neighbours in Nazareth - a wish fulfilment that Rasha Salti has described in her discussions of national symbolism across multiple Palestinian art forms (Salti 2010: 49). And yet the absurdity of both small acts of aggression, and massive acts of destruction, seem to support one another. The tank scene in Divine Intervention is perhaps the most 'Tati-like' sequence in the film: ES's shift from immobile avatar to force of destruction seems also to indicate a shift from Buster Keaton-esque world-weariness to the forces of chaos more akin to Jacques Tati's infamous figure, M. Hulot - particularly in Tati's combination of mute attentiveness and his trail of chaotic forces in oppositional reaction to the stilled postmodernist architecture of contemporaneous Paris in Playtime (1967). The transcultural implications of these absurd shifts from gestures of mute immobility to instants of chaotic destruction are as deeply rooted in cinematic forms across national borders, as the absurdity of the episodes are rooted in the particular spatial poetics and geo-political critique of Palestine.

\section{CONCLUSION}

This article cannot hope to map exhaustively the structural and formal resonances between Suleiman's filmmaking and a French and/or European literary and cultural imaginary. There is an argument to be made, that the traces and putative dialogues of Franco-Palestinian transcultural relations outlined in this article, might be nothing more than the cultural resonances effected by the work of an auteurist filmmaker, deeply immersed in the history of cinema. But that 'nothing more' is deceptive: that a Palestinian filmmaker like Suleiman should also be funded and supported extensively by French production, promotion and distribution networks; that his work combines 
both a complex understanding of film history in addition to its nods to the international geo-politics of the Middle East with regard to Europe and France and its acknowledgement of subjective frameworks of understanding these issues; that the films effectively become homages to cinema and yet also produce rich and complex critical aesthetics with regard to concepts such as humour and bodily oppression that recognises the pull of intercultural and French absurdist contexts; all these elements suggest that modalities of transcultural relations are more than casual, intertextual or biographical references. As Paul Martin Eve points out, Suleiman's films imply a form of 'critical antinationalism' (Eve 2010, 147) that deliberately conflates and confuses the positioning of national borders and cultures: an issue which raises an all too clear analogy with an argument for Palestinian liberation that has consistently emerged in interviews with Suleiman. Suleiman resists the notion of the nation state of Palestine in equal measure to his resistance of a notion of a unified or exclusive Israel. It is unsurprising, therefore, that the unspoken, implicit, above all cinematic transcultural relations in his filmmaking should also refuse consistent and linear 'mapping' as such. The poetic abstractions and non-linearities of Divine Intervention and The Time That Remains pertain also to a refusal of chronologies and neo-realisms that might situate Palestinian filmmaking as only Palestinian, rather than implicitly and explicitly connected to both its near neighbours and its European contextual relations. His films pertain both to global politics and to non-universal subjectivity. Hamid Dabashi argues that the polyglossia which permeatea the work of Suleiman and his Palestinian poet contemporary Mahmoud Darwish, operate as intertextual models for the political rhetorics that have sprung forth in the form of the 'Arab Spring': 
The hybrid nature of the political language we hear emanating from the Arab Spring advances a literary polyglossia that cannot be ideologically anchored or imperially appropriated. The relation between indexical utterances is predicated on literary intertextuality. In any such utterance the social actor appropriates the words of others and populates them with powerful intent. (Dabashi 2012, 225)

This intertextual resistance to fully articulating, and thus delimiting the potential for transcultural relationalities between Palestine, France, Europe, the Middle East, and North America, is also a political act of re-appropriation. In this, Suleiman both resists the speaking of a Franco-Palestinian 'dialogue' while upholding the possibility of continued transcultural intertextuality and political engagement. In this poetic, heteroglossic model of transcultural filmmaking, his films offer hope for a new, plural discourse of transcultural relations.

\section{BIBLIOGRAPHY}

Al-Jazeera. 2013. Dozens of hostages 'killed' in Algeria. Al Jazeera, 17 January, http://www.aljazeera.com/news/africa/2013/01/201311713160194432.html Accessed 17 January 2013.

Austin, Guy. 2012. Algerian National Cinema. Manchester: Manchester University Press.

Beckett, Samuel. 1957. Fin de partie. Paris: Minuit.

Beckett, Samuel. 1959. Krapp's Last Tape. London: Faber and Faber

Beckett, Samuel. 1967. Eh Joe and Other Writings. London: Faber.

Bergfelder, Tim. 2005. National, transnational or supranational cinema?: Rethinking European film studies', Media, Culture \& Society 27:3, 315-331 
Dabashi, Hamid. 2012. The Arab Spring: The End of Postcolonialism. London: Zed Books.

Elsaesser, Thomas. 2005. European Cinema: Face to Face with Hollywood. Amsterdam: Amsterdam University Press.

Esslin, Martin. 1970. Theatre of the Absurd. London: Penguin.

Eve, Martin Paul. 2010. The Time That Remains: Elia Suleiman and the London Palestinian Film Festival 2010. Excursions 1:1 (June): 146 -151.

Ezra, Elizabeth, and Terry Rowden (eds.). 2006. Transnational Cinema: The Film Reader. London: Routledge.

Galt, Rosalind. 2006. The New European Cinema: Redrawing the Map. NY:

Columbia University Press.

Gertz, Nurith, and George Khleifi. 2008. Palestinian Cinema: Landscape, Trauma and Memory. Edinburgh: Edinburgh University Press.

Gogol, Nikolai. 2011 [1836]. The Nose. Trans. Peter Constantine. New York (?): Alan Rodgers Books.

Harbord, Janet. 2007. The Evolution of Film: Rethinking Film Studies. Cambridge and Malden: Polity Press.

Harrison, Olivia C. 2012. Staging Palestine in France-Algeria: Popular Theater and the Politics of Transcolonial Comparison. Social Text 112 30: 3 (Fall): 27-47.

Hiddleston, Jane. 2006. Assia Djebar: Out of Algeria. Liverpool: Liverpool University Press.

Higbee, Will and Song Hwee Lim. 2010. Concepts of Transnational Cinema: Towards a Critical Transnationalism in Film Studies. Transnational Cinemas 1:1 : 721. 
Higson, Andrew. 2002. The Concept of National Cinema. In Film and Nationalism, ed. Andy Williams, 52-67, New Brunswick, NJ; London:

Rutgers University Press.

Jacinto, Leela. 2002. No Room for Palestinian Film at the Oscars. $A B C$ News, 20 December, http://abcnews.go.com/International/story?id=79485\&page=1. Accessed 17 January 2013.

Marks, Laura U. 1999. The Skin of the Film: Intercultural Cinema, Embodiment, and the Senses. Durham, NC and London: Durham University Press.

Le Monde. 2013. Prise d'otages en Algérie : le point sur la situation. Le Monde, 17 January, http://www.lemonde.fr/afrique/article/2013/01/17/prise-d-otages-en-algerie-

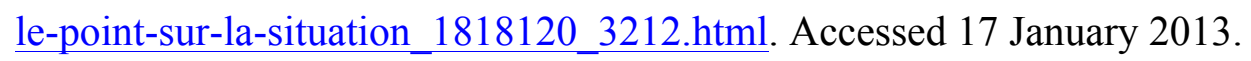

Morag, Raya. 2008. The Living Body and the Corpse-Israeli Documentary Cinema and the Intifadah. Journal of Film and Video 60:3-4 (Fall/Winter) 3-24

Naficy, Hamid. 2001. An Accented Cinema: Exilic and Diasporic Filmmaking. Princeton: Princeton University Press.

Pisters, Patricia. 2010. Violence and Laughter: Paradoxes of Nomadic Thought in Postcolonial Cinema. In Deleuze and Postcolonialism, ed. Simone Bignall and Paul Patton, 201-219. Edinburgh: Edinburgh University Press.

Rich, B. Ruby. 2003. Divine comedy: Elia Suleiman's surreal slapstick Divine Intervention fights brutality with imagination. San Francisco Bay Guardian, 26 March, http://www.sfbg.com/37/26/art_film_divine.html. Accessed 26 January 2013. Rondot, Philippe. 1987. France and Palestine: From Charles de Gaulle to François Mitterrand. Journal of Palestine Studies 16:3 (Spring): 87-100. 
Salti, Rasha. 2010. From Resistance and Bearing Witness to the Power of the Fantastical: Icons and Symbols in Palestinian Poetry and Cinema. Third Text 24:1: $39-52$.

Shlensky, Lincoln Z. 2010. Otherwise Occupied: The Israeli-Palestinian Conflict in the Francophone Cinema. In Israeli-Palestinian Conflict in the Francophone World, ed. Nathalie Debrauwere-Miller, 105-119. London: Routledge.

Shohat, Ella and Robert Stam. 1994. Unthinking Eurocentrism: Multiculturalism and the Media. London: Routledge.

Sieffert, Denis. 2004. Israël-Palestine: une passion française. Paris: La Découverte.

Suleiman, Elia and Aaron Cutler. 2011. Elia Suleiman. Bomblog, 18 January, http://bombsite.com/issues/1000/articles/4802. Accessed 10 January 2013.

Suleiman, Elia and Anne Bourlond. 2000. A Cinema of Nowhere: Interview with Elia Suleiman. Journal of Palestine Studies 29:2 (Winter): 95-101

Suleiman, Elia and Linda Butler. 2003. The Occupation (and Life) Through an Absurdist Lens. Journal of Palestine Studies 32:2 (Winter): 63-73.

Thirion, Antoine. 2009. La question du vampire: Le Temps qu'il reste d'Elia Suleiman. Cahiers du cinéma 647 (July-August): 33-35.

\section{Filmography}

Le Ballon Rouge. Directed by Albert Lamorisse. France: Montsouris Films, 1956.

Bab El Shams. Directed by Yousry Nasrallah. France/Egypt/Morocco: Multiple production sources including Ognon Pictures, arte France Cinéma, MISR International Films, Soread-2M, Gimages, Centre National de la Cinématographie (CNC), France 2 (FR2), Danmarks Radio (DR), Radio Télévision Belge Francophone (RTBF), TV5, 2004. 
Chronicle of a Disappearance. Directed by Elia Suleiman. Israel/Palestine: Centre National de la Cinématographie (CNC), Independent Television Service (ITVS), Programme MEDIA de la Communauté Européenne, 1996.

Divine Intervention: A Chronicle of Love and Pain. Directed by Elia Suleiman. Israel/Palestine: Filmstiftung Nordrhein-Westfalen, Gimages, Lichtblick Filmund Fernsehproduktion (II), Ness Communication \& Productions Ltd., Ognon Pictures, Soread-2M, arte France Cinéma, CNC, 2002.

Five Broken Cameras. Directed by Emad Burnat and Guy Davidi. Israel/Palestine: Alegria Productions, Burnat Films, Guy DVD Films, 2011.

Le Voyage du ballon rouge/Flight of the Red Balloon. Directed by Hou Hsaio Hsien. France/Taiwan: multiple production sources including 3H Productions, Margo Films, Les Films du Lendemain, arte France Cinéma, Le Musée d'Orsay, Canal+, CinéCinéma, Sofica Poste Image, Région Ile-de-France, Soficinéma 3, 2007.

Ici et Ailleurs/Here and Elsewhere. Directed by Jean-Luc Godard, Jean-Pierre Gorin and Anne-Marie Miéville. France/Israel: Gaumont, Sonimage, 1976.

Laïcité, Inch'allah! Directed by Nadia al-Fani. France/Tunisia: K'Ien Productions, Z'Yeux Noirs Movies. 2011.

Paradise Now. Directed by Hany Abu-Assad. Palestine/Israel: multiple production sources including Augustus Film, Lama Productions, Razor Film Produktion GmbH, Lumen Films, arte France Cinéma, Hazazah Film, Eurimages, Filmstiftung Nordrhein-Westfalen, Lama Films, Medienboard BerlinBrandenburg, Nederlands Fonds voor de Film, 2005.

Playtime. Directed by Jacques Tati. France: Jolly Film, Specta Films, 1967. 
Le Temps qu'il reste/The Time That Remains. Directed by Elia Suleiman. Israel/Palestine: multiple production sources including Nazira Films, France 3 Cinéma, Artemis Films, Radio Télévision Belge Francophone (RTBF), BIM Distribuzione, Belgacom TV, Corniche Pictures, Canal+, Eurimages, 2009.

\footnotetext{
${ }^{1}$ News source Al-Jazeera suggested early on that the Amenas siege was initiated by an Islamic group 'in retaliation for Algeria letting France use its airspace to launch operations against rebels in northern Mali.' Le Monde admitted its own confusion amidst the plethora of news reports by titling its article 'Que sait-on sur la prise d'otages en Algérie?'
} 